\title{
KEPEMIMPINAN KEPALA SEKOLAH DALAM PENINGKATAN KINERJA GURU
}

\author{
Oleh : \\ Uray Iskandar ${ }^{1}$
}

\begin{abstract}
Abstrak Dalam proses pembelajaran guru dipandang memiliki peran penting terutama dalam membantu peserta didik untuk mengembangkan potensinya dalam kemampuan kognitif, afektif dan psikomotor, guru juga berupaya untuk membangkitkan rasa ingin tahu, mendorong kemandirian dan ketepatan logika intelektual, serta menciptakan kondisi-kondisi untuk sukses dalam belajar. Kinerja guru dapat dilihat dan diukur berdasarkan spesifikasi/kriteria kompetensi yang harus dimiliki oleh setiap guru. dapat ditampilkan melalui penguasaan kompetensi pedagogik, profesional, kepribadian dan sosial. Mengingat kepemimpinan dan motivasi kerja kepala sekolah terhadap kinerja guru memberikan suatu korelasi, maka disarankan pada SMP Negeri Teluk Keramat, bahwa guru dapat meningkatkan kinerja dapat dilihat dari tanggungjawabnya menjalankan tugas profesi yang diembannya, kepatuhan dan loyalitasnya di dalam menjalankan tugas keguruan sebagai guru.
\end{abstract}

Kata Kunci : Kepemimpinan Kepala Sekolah, Peningkatan Kinerja Guru

\section{Pendahuluan}

Guru dalam proses pembelajaran memiliki peran penting terutama dalam membantu peserta didik untuk membangun sikap positif dalam belajar, membangkitkan rasa ingin tahu, mendorong kemandirian dan ketepatan logika intelektual, serta menciptakan kondisi-kondisi untuk sukses dalam belajar.

Prajudi Atmosudirdjo (1982:60) dalam Martinis Yamin \& Maisah (2010:26) menyebutkan bahwa guru memiliki peran yag sangat besar dalam pendidikan, di pundaknya dibebani suatu tanggung jawab atas mutu pendidikan. Maka dari itu guru harus mengembangkan dirinya dengan meningkatkan kompetensi dan kinerjanya.

\footnotetext{
${ }^{1}$ Uray Iskandar adalah Pengawas SMP Dinas Pendidikan Kabupaten Sambas
} 
Tugas utama guru adalah membimbing, membantu, mengarahkan peserta didik kedewasaaannya. Hal ini sejalan dengan pendapat Martinis Yamin \& Maisah, (2010:87) bahwa kinerja guru menyangkut seluruh aktivitas yang ditunjukkan oleh tenaga pengajar dalam tanggungjawabnya sebagai seorang yang mengemban suatu amanat dan tanggung jawab untuk mendidik, mengajar, membimbing, mengarahkan, dan memandu peserta didik dalam rangka menggiring perkembangan peserta didik kearah kedewasaan mental-spiritual maupun fisik-bilogis.

Peraturan Pemerintah (PP) Nomor 19 Tahun 2005 tentang Badan Standar Nasional Pendidikan (BSNP) menegaskan bahwa pendidik (guru) harus memiliki kompetensi sebagai agen pembelajaran pada jenjang pendidikan dasar dan menengah serta pendidikan anak usia dini. Arahan normatif tersebut yang menyatakan bahwa guru sebagai agen pembelajaran menunjukkan pada harapan, bahwa guru merupakan pihak pertama yang paling bertanggung jawab dalam pentransferan ilmu pengetahuan kepada peserta didik.dan juga harus menguasai kompetensi pedagogik, kepribadian, profesional dan sosial

Kompetensi pedagogik, merupakan kemampuan dalam pengelolaan peserta didik meliputi pemahaman wawasan guru akan ladasan dan filsafat pendidikan, pemahaman potensi dan keberagaman peserta didik. Kompetensi kepribadian, guru sebagai teladan bagi murid-muridnya harus memiliki sikap dan kepribadian utuh yang dapat dijadikan tokoh panutan idola dalam seluruh segi kehidupannya. Kompetensi profesional, tugas utama mendidik, mengajar, membimbing, mengarahkan, melatih, menilai dan mengevaluasi peserta didik. Kompetensi sosial, kemampuan guru untuk berkomunikasi dan bergaul secara efektif dengan peserta didik, sesama pendidik, tenaga kependidikan, orang tua/wali peserta didik dan masyarakat sekitar..

Guru yang bermutu niscaya mampu melaksanakan pendidikan, pengajaran dan pelatihan yang efektif dan efisien. Mereka diyakini mampu memotivasi siswa untuk mengoptimalkan potensinya dalam kerangka pencapaian standar pendidikan yang ditetapkan. Kemampuan mengajar guru yang sesuai dengan tuntutan standar tugas yang diemban memberikan efek positif bagi hasil yang ingin dicapai seperti perubahan hasil akademik siswa, sikap siswa, keterampilan siswa, dan perubahan pola kerja guru yang semakin meningkat. 
Sekolah mempunyai peranan yang sangat besar dalam mencerdaskan kehidupan bangsa dengan memberikan pelayanan yang baik kepada siswa. Sebelum memberikan pelayanan kepada siswa maka guru yang terlibat dalam proses belajar mengajar juga harus diperhatikan kinerjanya

Untuk mewujudkan tujuan di atas diperlukan seorang pemimpin atau kepala sekolah yang mampu memanage sekolah dengan baik dan memiliki motivasi kerja yang tingggi, serta mampu menciptakan lingkungan sekolah yang kondusif dapat mendukung kinerja guru yang berakhir pada peningkatan prestasi siswa.

Kepala sekolah sebagai pimpinan tertinggi yang sangat berpengaruh dan menentukan kemajuan sekolah harus memiliki kemampuan administrasi, memiliki komitmen tinggi, dan luwes dalam melaksanakan tugasnya. Kepemimpinan kepala sekolah yang baik harus dapat mengupayakan peningkatan kinerja guru melalui program pembinaan kemampuan tenaga kependidikan. Oleh karena itu kepala sekolah harus mempunyai kepribadian atau sifat-sifat dan kemampuanserta keterampilan-keterampilan untuk memimpin sebuah lembaga pendidikan

Hal ini disebabkan karena pemimpin adalah orang yang berada di barisan paling depan yang diharapkan para pengikut untuk mengarahkan mereka, sehingga tidaklah mengherankan apabila pemimpin yang efektif atau "pemimpin yang baik" pada umumnya sangat pandai untuk memotivasi diri sendiri (self motivated) dan memotivasi para pengikutnya.

Sebagai motivator, kepala sekolah harus memiliki strategi yang tepat untuk memberikan motivasi kepada para tenaga pendidik dalam melakukan tugasnya. Memberikan motivasi terhadap guru dapat terdiri atas pemberian penghargaan yang dapat menumbuhkan inisiatif, kemampuan-kemampuan kreatif, dan semangat berkompetisi yang sehat. Penghargaan ini sangat penting untuk meningkatkan mutu kinerja tenaga pendidik, dan untuk mengurangi kegiatan yang kurang produktif.

Motivasi pada dasarnya merupakan kondisi mental yang mendorong pemimpin melakukan suatu tindakan atau aktivitas dan memberikan kekuatan yang mengarah kepada pencapaian pemenuhan keinginan, kebutuhan, memberi kepuasan, ataupun mengurangi ketidakseimbangan. Dalam hal ini motivasi mengacu pada faktor-faktor yang menggerakkan dan mengarahkan tingkah laku yang melibatkan dorongan perbuatan tersebut terhadap tujuan tertentu. Abraham Maslow (Stephen P. Robbin, 1996) menghipotesiskan 
adanya lima jenjang kebutuhan dalam diri semua manusia, yaitu dimulai dari kebutuhan psikologis, keamanan, social, penghargaan, dan yang paling tinggi, aktualisasi diri.

Demikian keterkaitan kepemimpinan kepala sekolah dan motivasi kerja, merupakan faktor yang saling mempengaruhi terhadap kinerja guru. Demikian halnya dengan kinerja guru ditentukan oleh tingkat sejauh mana kepemimpinan dan motivasi kerja. Kelangsungan hidup dan keberhasilan sekolah pada masa kini tergantung pada kemampuan pemimpinnya dalam mengantisipasi perubahan eksternal. Dalam hal ini, sekolah harus memilki kepala sekolah yang efektif dalam menjalankan kepemimpinannya. Tantangan bagi kepala sekolah adalah bagaimana menjadi pendorong atau pelopor perubahan sekolah yang dipimpinnya.

Hal tersebut menjadi lebih penting sejalan dengan semakin kompleksnya tuntutan tugas kepala sekolah,yang menghendaki dukungan kinerja yang semakin efektif dan efisien. Davi F Salisbury (1996:149) dalam Suryadi (2009:70) menjelaskan "without quality leadership and skillful management, even the ideas are never implemented. Witouth good management and on going support for their leaders, those lower in the organization become disillusioned in time, case to continue the change effort". Upaya perbaikan mutu dalam suatu organisasi sangat ditentukan oleh mutu kepemimpinan dan manajemen yang efektif. Dukungan dari bawah hanya akan muncul secara berkelanjutan ketika pimpinannya benar-benar bermutu atau unggul.

Berdasarkan fakta di lapangan bahwa kepemimpinan kepala sekolah sangat penting dan akan berpengaruh terhadap pelaksanaan tugas guru di sekolah yang akhirnya akan berpengaruh juga pada pencapaian tujuan pendidikan yang diharapkan. Selain itu dengan motivasi kerja kepala sekolah akan dapat mempengaruhi peningkatan kinerja guru dan tenaga pendidik lainnya di sekolah.

\section{Kepemimpinan Kepala Sekolah}

Kepala sekolah yang berhasil apabila mereka memahami keberadaan sekolah sebagai organisasi yang komplek dan unik serta mampu melaksanakan peranan kepala sekolah sebagai seorang yang diberi tanggung jawab untuk memimpin sekolah. Dalam mengelola sekolah, kepala sekolah memiliki peran yang sangat besar. Kepala sekolah merupakan motor 
penggerak, penentu arah kebijakan menuju sekolah dan pendidikan secara luas.

Kepemimpinan kepala sekolah merupakan kemampuan untuk menggerakkan tenaga kependidikan, sehingga tujuan pendidikan yang telah ditetapkan dapat tercapai secara efektif dan efisien. Kepemimpinan Kepala Sekolah merupakan salah satu faktor yang dapat mendorong sekolah untuk mewuudkan visi, misi, tujuan, dan sasaran sekolah melalui program-program yang dilaksanakan secara terencana dan bertahap. Dalam mengarahkan visi dan misi pemimpin harus tnenetapkan tujuan ke arah kegiatan yang tepat dan memerintahkan untuk bergerak.

Kepala Sekolah adalah pemimpin pendidikan pada tingkat sekolah, sehingga ia juga harus menghindarkan diri dari wacana retorika dan perlu membuktikan bahwa ia memiliki kemampuan kerja secara profesional serta menghindarkan diri dari aktivitas yang dapat menyebabkan pekerjaan yang ada disekolah menjadi sangat membosankan.

Kepala sekolah merupakan orang atau personil kependidikan yang memiliki peran besar dalam mencapai keberhasilan pengelolaan suatu sekolah, sedangkan guru berada posisi lain yang berperan besar dalam keberhasilan proses belajar mengajar di dalam kelas disamping peran siswa, karyawan sekolah dan juga orang tua siswa. Kualitas kepemimpinan kepala sekolah yang didalamnya terdapat juga kepribadian, ketrampilan dalam mengelola sekolah termasuk dalam menangani masalah yang timbul disekolah, gaya kepemimpinan serta kemampuan menjalin hubungan antar manusia sangat menentukan atau memiliki pengaruh yang besar terhadap kualitas proses belajar dan mengajar di sekolah.

Dalam hal ini keberhasilan kepala sekolah dalam memimpin sekolah akan tampak dari apa yang dikerjakannya. Hal ini penting untuk dikedepankan karena apa yang telah dikerjakan kepala sekolah melalui kebijakan yang telah ditetapkan akan mempengaruhi kondisi fisik dan psikis para guru, siswa dan karyawan sekolah. Guru akan dapat melaksanakan tugas dengan penuh rasa tanggung jawab apabila ia merasa puas terhadap kepemimpinan kepala sekolah. Oleh sebab itu seorang kepala sekolah dalam memimpin agar tujuan yang telah ditetapkan dapat tercapai dengan baik ia juga harus memperhatikan secara kultural, baik bagi guru, siswa, karyawan sekolah, orang tua siswa serta lingkungan masyarakat. 
Menurut Mulyasa, dalam Deni Koswara (2008:57) kepemimpinan seseorang sangat berkaitan dengan kepribadian, dan keperibadian kepala sekolah sebagai pemimpin akan tercermin dalam sifat-sifat yang jujur, percaya diri, tanggung jawab, berani mengambil resiko dan keputusan, berjiwa besar, emoso yang stabil dan teladan.

Selanjutnya menurut Mulyono ( 2008:143) kepemipinan kepala sekolah merupakan ruh yang menjadi pusat sumber gerak organisasi untuk mencapai tujuan dalam meningkatkan kesempatan untuk mengadakan pertemuan secara efektif dengan para guru dalam situasi yang kondusif. Perilaku kepala sekolah harus dapat mendorong kinerja para guru dengan menunjukkan rasa bersahabat, dekat dan penuh pertimbangan terhadap para guru, baik sebagai individu maupun sebagai kelompok.

Berdasarkan uraian tersebut di atas, seorang kepala sekolah pada hakikatnya adalah seorang perencana, organisator, pemimpin dan seorang pengendali. Keberadaan seorang kepala sekolah diperlukan untuk mencapai suatu tujuan yang telah ditetapkan dimana di dalam organisasi yang di pimpinnya berkembang berbagai macam pengetahuan serta organisasi yang menjadi tempat untuk membina dan mengembangkan karir sumber daya manusia.

Kepemimpinan kepala sekolah yang efektif dapat dilihat berdasarkan kriteria, mampu memberdayakan guru untuk melaksanakan proses pembelajaran dengan baik, lancar dan produktif. Kepala sekolah dapat menjelaskan tugas dan pekerjaannya sesuai waktu yang telah ditetapkan, mampu membangun hubungan yang harmonis dengan guru dan masyarakat dalam rangka mewujudkan tujuan sekolah.

Menurut Wahjosumidjo ( 2008:102 ) bahwa kepemimpinan kepala sekolah terdiri dari :

a. kepemimpinan yang berorientasi pada tugas (struktur initiang) yang meliputi : mengutamakan pencapaian tujuan, menilai pelaksanaan tugas bawahan, menetapkan batas-batas waktu pelaksanaan tugas, menetapkan standar tertentu terhadap tugas bawahan, memberi petunjuk-petunjuk kepada bawahan, melakukan pengawasan secara ketat terhadap tugas.

b. kepemimpinan yang berorientasi pada hubungan manusia yang meliputi : melibatkan bawahan dalam pengambilan keputusan, bersikap bersahabat, membina hubungan kerjasama dengan baik, membeerikan dukungan 
terhadap bawahan, menghargai ide atau gagasan, memberi kepercayaan terhadap bawahan.

Kepala Sekolah sebagai pemimpin pendidikan yaitu bertanggung jawab dalam menciptakan suatu situasi belajar mengajar yang kondusif, sehingga guru-guru dapat melaksanakan pembelajaran dengan baik dan peserta didik dapat belajar dengan tenang. Disamping itu Kepala Sekolah dituntut untuk dapat bekerja sama dengan bawahannya, dalam hal ini guru dan staf TU.

Guru memerlukan motivasi yang berasal dari luar dirinya yang tentu saja sangat perlu diperhatikan oleh manajer atau Kepala Sekolah. Namun demikian dalam motivasi dimulai dari dalam diri guru itu sendiri. Dorongan dari dalam diri sendiri akan lebih berhasil daripada dorongan dari luar. Motivasi kerja kepala sekolah adalah mengarahkan, dan mendorong seorang guru untuk melakukan tindakan dan mengatasi segala tantangan dan hambatan dalam upaya untuk mencapai tujuan pendidikan.

Dengan peningkatan kemampuan atas segala potensi yang dimilikinya itu, maka dipastikan guru-guru yang juga merupakan mitra kerja kepala sekolah dalam berbagai bidang kegiatan pendidikan dapat berupaya menampilkan sikap positif terhadap pekerjaannya dan meningkatkan kompetensi profesionalnya.

Menurut Wahjosumidjo (2010:81) kepala sekolah yang berhasil apabila mereka memahami keberadaan sekolah sebagai organisasi yang komplek dan unik serta mampu melaksanakan peranan kepala sekolah sebagai seseorang yang diberi tanggung jawan untuk memimpin sekolah.

Selanjutnya menurut Tim Dosen AP UPI ( 2008:126) kepemipinan pendidikan merupakan kemampuan untuk menggerakkan pelaksanaan pendidikan sehingga tujuan pendidikan yang telah ditetapkan dapat tercapai secara efektif dan efisien. Sedangkan menurut pendapat Dadi Permadi ( 2009: 24) bahwa kepemimpinan kepala sekolah dalam mengarahkan dan memanfaatkan segala sumber daya yang tersedia sangat menentukan keberhasilan proses belajar di sekolah.

\section{Peningkatan Kinerja Guru}

Kinerja merupakan serangkaian kegiatan yang menggambarkan sejauhmana hasil yang sudah dicapai oleh seseorang dalam melaksanakan tugas dan tanggung jawabnya dalam bentuk akuntabilitas publik, baik berupa keberhasilan maupun kekurangan yang terjadi. Kinerja mensyaratkan adanya 
semangat kerja yang di dalamnya termasuk beberapa nilai keberhasilan baik untuk organisasi maupun seseorang. Kinerja guru menurut Martinis Yamin dkk (2010: 87) adalah merupakan hasil kerja seluruh aktivitas dari seluruh komponen sumber daya yang ada. Kinerja merupakan perilaku atau respon yang memberi hasil yang mengacu kepada apa yang mereka kerjakan ketika dia menghadapi suatu tugas.

Guru merupakan profesi profesional di mana ia dituntut untuk berupaya semaksimal mungkin menjalankan profesinya sebaik mungkin. Sebagai seorang profesional maka tugas guru sebagai pendidik, pengajar dan pelatih hendaknya dapat berimbas kepada siswanya. Dalam hal ini guru hendaknya dapat meningkatkan terus kinerjanya yang merupakan modal bagi keberhasilan pendidikan.

Guru merupakan elemen kunci dalam sistem pendidikan, khususnya di sekolah. Semua komponen lain, mulai dari kurikulum, sarana-prasarana, biaya, dan sebagainya tidak akan banyak berarti apabila esensi pembelajaran yaitu interaksi guru dengan peserta didik tidak berkualitas. Semua komponen lain, terutama kurikulum akan "hidup" apabila dilaksanakan oleh guru. Begitu pentingnya peran guru dalam mentransformasikan input-input pendidikan, sampai-sampai banyak pakar menyatakan bahwa di sekolah tidak akan ada perubahan atau peningkatan kualitas tanpa adanya perubahan dan peningkatan kualitas guru.

Mengingat peranan strategis guru dalam setiap upaya peningkatan mutu, relevansi dan efisiensi pendidikan, maka pengembangan profesionalisasi guru merupakan kebutuhan (Udin Syaefudin Saud, 2009:97). Menurut Uhar Suharsaputra ( 2010: 144) bahwa kinerja atau performance berarti tindakan menampilkan atau melaksanakan suatu kegiatan. Kinerja merupakan suatu kemampuan kerja atau prestasi kerja yang diperlihatkan oleh seorang pegawai untuk memperoleh hasil kerja yang optimal. Kinerja seseorang akan tampak pada situasi dan kondisi kerja sehari-hari. Aktivitasaktivitas yang dilakukan oleh seseorang dengan melaksanakan pekerjaannya menggambarkan bagaimana ia berusaha mencapai tujuan yang telah ditetapkan.

Kinerja diartikan prestasi kerja atau pelaksanaan kerja atau hasil unjuk kerja. Kinerja adalah hasil dari suatu proses yang dilakukan manusia. Kinerja merupakan suatu wujud perilaku seseorang atau organisasi dengan orientasi prestasi. ( Dirjen PMPTK Depdiknas, 2008: 20 )

Keberhasilan guru seseorang bisa dilihat apabila kriteria-kriteria yang ada telah mencapai secara keseluruhan. Jika kriteria telah tercapai berarti 
pekerjaan seseorang telah dianggap memiliki kualitas kerja yang baik. Sebagaimana yang telah disebutkan dalam pengertian kinerja bahwa kinerja guru adalah hasil kerja yang terlihat dari serangkaian kemampuan yang dimiliki oleh seorang yang berprofesi guru. Kemampuan yang harus dimiliki guru telah disebutkan dalam peraturan pemerintah RI No. 19 Tahun 2005 tentang Standar Nasional Pendidikan pasal 28 ayat 3 yang berbunyi: Kompetensi sebagai agen pembelajaran pada jenjang pendidikan dasar dan menengah serta pendidikan anak usia dini yang meliputi (1) kompetensi pedagogik, (2) kompetensi kepribadian, (3) kompetensi professional, (4) kompentensi sosial

Menurut Mortimer J. Adler, dalam Permadi (2009:24) menyatakan bahwa mutu belajar mengajar yang terjadi di sekolah adalah ditentukan oleh sebagian besar mutu kepemimpinan kepala sekolah. Kinerja guru tercapai dengan baik terlihat dari guru yang rajin hadir di sekolah dan rajin dalam mengajar, guru mengajar dengan sungguh-sungguh menggunakan rencana pelajaran, guru mengajar dengan semangat dan senang hati, menggunakan media dan metode mengajar yang sesuai dengan materi pelajaran, melakukan evaluasi pengajaran dan menindaklanjuti hasil evaluasi. Apa yang dilakukan oleh guru ini akan berdampak kepada keberhasilan siswa dalam proses belajar mengajar.

\section{Kesimpulan}

Kepala Sekolah adalah pemimpin pendidikan pada tingkat sekolah, sehingga ia juga harus menghindarkan diri dari wacana retorika dan perlu membuktikan bahwa ia memiliki kemampuan kerja secara profesional serta menghindarkan diri dari aktivitas yang dapat menyebabkan pekerjaan yang ada disekolah menjadi sangat membosankan.

Kepala Sekolah harus mampu menanamkan, memajukan, dan meningkatkan nilai mental, moral, fisik dan artistik kepada para guru atau tenaga fungsional yang lainnya, tenaga administrasi (staf) dan kelompok para siswa atau peserta didik. Untuk menanamkan peranannya ini Kepala Sekolah harus menunjukkan sikap persuasif dan keteladanan. Sikap persuasif dan keteladanan inilah yang akan mewarnai kepemimpinan termasuk didalamnya pembinaan yang dilakukan oleh Kepala Sekolah terhadap guru yang ada di sekolah tersebut

Kepala sekolah harus memiliki rasa tanggung jawab yang besar dalam meningkatkan kinerja guru melalui motivasi kerja kepala sekolah yang merupakan kesediaan untuk mengeluarkan tingkat upaya yang tinggi ke 
arah tujuan organisasi, yang dikondisikan oleh kemampuan upaya itu untuk memenuhi sesuatu kebutuhan individual.

Kinerja guru akan meningkat jika guru telah melakukan unsur-unsur yang terdiri dari kesetiaan dan komitmen yang tinggi pada tugas mengajar, menguasai dan mengembangkan bahan pelajaran, kedisiplinan dalam mengajar dan tugas lainnya, kreativitas dalam pelaksanaan pengajaran, kerjasama dengan semua warga sekolah, kepemimpinan yang menjadi panutan siswa, kepribadian yang baik, jujur dan objektif dalam membimbing siswa, serta tanggung jawab terhadap tugasnya. Oleh karena itu tugas kepala sekolah selaku manager adalah melakukan penilaian terhadap kinerja guru. Penilaian ini penting untuk dilakukan mengingat fungsinya sebagai alat motivasi bagi pimpinan kepada guru maupun bagi guru itu sendiri

\section{Daftar Pustaka}

Direktorat Tenaga Kependidikan Dirjen PMPTK.2008. Penilaian Kinerja Guru. Jakarta.

Koswara, Deni.2008.Kebiasaan Kepala Sekolah Efektif. Bandung. Pribumi Mekar

Mulyono.2008. Manajemen Adminstrasi \& Organisasi Pendidikan. Malang. Arruzzmedia.

Peraturan Pemerintah (PP) Nomor 19 Tahun 2005 tentang Badan Standar Nasional Pendidikan (BSNP)

Permadi, Dadi. 2009. Kepemimpinan Mandiri ( Profesional) Kepala Sekolah. Bandung. Sarana Panca Karya Nusa

Robbins, S. 2010.Teori Organisasi Struktur, Desain \& Aplikasi.Arcan.

Saud, US. 2009. Pengembangan Profesi Guru. Bandung. Alfabeta.

Suharsaputra, Uhar.2010. Administrasi Pendidikan. Bandung.Refika Aditama.

Suryadi.2009.Manajemen Berbasis Sekolah Konsep dan Aplikasi. Bandung. Sarana Panca Karya Nusa.

Tim Dosen AP UPI.2008. Manajemen Pendidikan. Bandung Alfabeta

Wahjosumidjo.2008. Kepemimpinan Kepala Sekolah.Jakarta. Raja Grafindo Persada.

Yamin, Martinis. dkk. 2010. Standarisasi Kinerja Guru. Jakarta.Gaung Persada 